\title{
Abortion in the times of Zika: the perspective of women in two Brazilian municipalities
}

\author{
Aborto en tiempos del Zika: la perspectiva de las mujeres \\ en dos municipios brasileños
}

\author{
Raquel Zanatta-Coutinho and Andréa Branco-Simão \\ Departamento de Demografia e Centro de Desenvolvimento e Planejamento \\ Regional (Cedeplar), Universidade Federal de Minas Gerais, Brazil
}

\section{Summary}

In Brazil, abortion is considered a crime under the Criminal Code since 1940. After the Zika virus epidemic (2015-2017) and the consequent appearance of microcephaly in newborns struck South America, the debate on the decriminalization of abortion in the Brazilian society was reignited. Using data obtained from focus groups comprising women of reproductive age across different socioeconomic strata and two Brazilian cities, we investigated the perceptions of the participants on abortion, especially its use during the Zika epidemic. Although legally criminalized, abortion is prevalent among women, as a way to fulfill their reproductive desire. Criminalization puts the health and lives of women at risk, particularly those with less economic and cultural capital. We also discover the role of friends in women's decision to utilize the procedure. The strong asymmetry of power between men and women contributes to the greater vulnerability of women. The results suggest an urgent need to review the legislation on abortion concerning its criminalization and the option of safer abortion within the scope of the public health service.

Keywords: Abortion; unsafe abortion; Zika vírus; decriminalization; Focus Groups; Brazil.

\section{Resumen}

La epidemia del virus del Zika (2015-2017) y la consecuente aparición de microcefalia en recién nacidos que azotaron la América del Sur, en particular Brasil, reavivó el debate sobre la despenalización del aborto en la sociedad brasileña, donde un crimen bajo el Código Penal vigente desde 1940. Utilizando datos de grupos focales realizados con mujeres en edad reproductiva, de diferentes estratos socioeconómicos y dos ciudades brasileñas, investigamos las percepciones de los participantes sobre el aborto, especialmente su uso durante la epidemia de Zika. Aunque legalmente criminalizado, mujeres siguen practicando el aborto como una forma de hacer efectivo el deseo reproductivo. La criminalización genera riesgos para la salud y la vida de las mujeres, particularmente aquellas con menos capital económico y cultural. También encontramos el papel de los amigos en la indicación del procedimiento y la fuerte asimetría de poder entre hombres y mujeres que contribuyen a la mayor vulnerabilidad de estos últimos. Los resultados analizados apuntan a la urgente necesidad de revisar la legislación que aborda el aborto con respecto a su criminalización y la oferta de un aborto seguro dentro del alcance del servicio de salud pública.

Palabras clave: Aborto; Aborto inseguro; Zika vírus; Despenalización; Grupos Focales; Brasil. 


\section{INTRODUCTION}

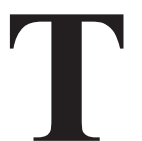

he relationship between the increase in the number of cases of children with microcephaly and congenital malformations (Congenital Zika virus syndrome, SCZ) during pregnancy and Zika virus infection was established by the end of 2015, followed by a resurgence of abortion conversations. This included discussions around prevalent gender, social and economic inequalities as well as restricted access to information, contraceptive methods, and health services (Baum et al., 2016; Pitanguy, 2016; Stern, 2016; Roa, 2016).

Abortion is not an easy problem to solve. It is associated with many controversies. In Brazil, the voluntary interruption of pregnancy is considered a crime under the Penal Code since 1940, with exceptions made for high-risk pregnancies, rape, and anencephaly. Clandestine and unsafe abortion emerge as a public health concern due to the criminalization of voluntary interruption of pregnancy, resulting in a spike in the annual number of maternal deaths. Despite advances in public health, deaths from unsafe abortion and unwanted pregnancies are persistent challenges (Menezes et al., 2019; Schuck-Paim et al., 2016).

Since the beginning of the Zika epidemic till the recent Covid-19 pandemic, it has been difficult to preserve health. Nothing has changed in terms of legislation or regulations (Carabali et al., 2018; Roa, 2016; Stern, 2016; Mohallem and Soares, 2016; Wenham et al., 2019). On the contrary, all attempts to amend the laws were aimed at increasing the criminalization of the procedure and even the withdrawal of sexual and reproductive rights already guaranteed to Brazilians by law. Abortion as a response to public health crises has been gradually ignored, despite the great movements and appeal of scientists, health managers, organized civil society, and international agencies such as the United Nations (Baum et al., 2016; Carabali et al., 2018; Diniz et al., 2020; Mohallem and Soares, 2016; Pitanguy, 2016; Stern, 2016; Wenham et al., 2019).

However, the abortion literature lacks empirical data. This article analyzes how women of reproductive age in Belo Horizonte (MG) and Recife (PE) perceived problems associated with abortion. It accounts for the increasing cases of children with microcephaly and congenital malformations associated with Zika infection during the gestational period in the years 2015-2017. Also, this article presents insights into problems fostered by restricted access to abortion and the dilemmas surrounding the termination of pregnancy in the event of the Zika virus. We evaluate the status 
quo to determine whether the Zika epidemic has progressed or revealed setbacks in policies on sexual and reproductive rights in the country.

Initially, we consider the emergence and consequences of Zika in Brazil, as well as the recent abortion scenario in the country. Then, we describe the methods and data used to develop the study. We illustrate our findings with quotes from the focus groups. Finally, we discuss and present our conclusion.

\section{The ZiKa VIRUS AND PUbliC HEALTh RESPONSES IN REPRODUCTIVE RIGHTS}

The Zika virus has established itself as a major challenge for the general population and public health authorities (Abrasco, 2016). Zika virus disease is an acute febrile disease marked by red patches on the skin, joint pain, conjunctivitis, and fever, transmitted by the mosquito Aedes aegypti via sexual and placental routes. For most people, it is a very mild infection that evolves towards a cure, but it may be more serious for pregnant women. The Zika virus has been associated with more serious neurological complications, such as Guillain-Barré syndrome (GBS), an autoimmune disease that causes generalized muscle weakness and paralysis, as well as microcephaly in newborns, a malformation in which normal brain growth is interrupted during pregnancy, generating a lower head circumference than expected (Garcia, 2018; Miranda-Filho et al., 2016). In addition to microcephaly and GBS, the Zika virus can also have other neurological effects on the development of the baby, including hearing and vision impairment, irritability, and swallowing problems, collectively known as Congenital Zika Syndrome (CZS) (Miranda-Filho et al., 2016).

In October 2015, the unexpected increase in the number of live births with microcephaly in northeastern Brazil caught the attention of the country's health authorities, after which a state of Public Health Emergency of National Importance (ESPIN) was declared. That same year, the Brazilian Ministry of Health launched the Surveillance and Response Protocol for the Occurrence of Microcephaly and/or Alterations in the Central Nervous System (CNS) related to the Zika virus, guiding personal protection measures to minimize exposure to the Zika virus, especially pregnant women (Brazil, 2015). In February 2016, the World Health Organization (WHO) declared the situation a Public Health Emergency of International Concern (PHEIC).

The Minister of Health informally suggested that couples and women postpone their plans to conceive for at least six months. The use of contra- 
ceptives for this purpose was encouraged. However, this political response to the Zika virus did not account for the fact that more than half of pregnancies in Brazil are unplanned; approximately one in five children is born to an adolescent mother (Roa, 2016; Schuck-Paim et al., 2016). Furthermore, the minister's directive lacked clarity. It failed to account for how women living in different parts of the country, with different socioeconomic statuses, would have access to contraceptive methods (Coutinho et al., 2021; Roa, 2016; Wenham et al., 2019). These hindrances question the feasibility of postponing childbearing and expose the weaknesses of a health policy that imposes the responsibility of fighting the virus on women, by controlling fertility (Coutinho et al., 2021).

In March 2016, the Ministry of Health published a new protocol, the Protocol for health care and response to the appearance of microcephaly (Brazil, 2016). Unlike the previous one, this protocol provides recommendations for the provision of care in reproductive planning contexts through prenatal and newborn care (Baum et al., 2016; Brazil, 2016). However, despite recognizing the importance of contraceptive methods in achieving the goal of postponing fertility, as extensively discussed by public health and gender scholars, the protocol does not mention the existing obstacles to the implementation of reproductive plans, such as restricted access to health facilities and safe contraceptive methods. No policies were made to combat the expensiveness and limited supply of contraceptive methods, the distance required to reach health facilities, the limited open hours of health units, or the shortage of human resources that characterize the reality of many health units in Brazil. Other challenges include the inequalities associated with sex education in schools, the inequities in gender relations (particularly in the context of intimate relationships), and the relationship between religion and decision-making on family planning (Baum et al., 2016; Coutinho et al., 2021; Roa, 2016; Wenham et al., 2019). Health professionals were not equipped with the knowledge of how to surmount these barriers and help women make informed reproductive decisions. These limitations mark the reality of the most vulnerable and less empowered women who, in general, are characterized by being younger, black, belonging to groups with low income or low education levels (Stern, 2016; Roa, 2016). The power of misinformation and myths about health and contraceptive methods in reproductive choices was evident in a qualitative study that interviewed adolescents in Zika-affected areas (Diniz et al., 2020).

In November 2016, the World Health Organization no longer treated Zika virus disease as an international public health emergency, but it was 
reconsidered a "common threat". In May 2017, the Brazilian Ministry of Health declared the end of the emergency in the country (Garcia, 2018). However, the sequence of events did not prevent many countries from recording the transmission of the Zika virus. On the contrary, this sequence exposed the risk imposed on the reproductive rights of women, reinforcing fears and stigmas (Linde et al., 2018; Moreira et al., 2018). The need to debate abortion in the country has reappeared, as unsafe procedures cause complications and serious consequences for women (Menezes et al., 2019; Stern, 2016). The number of unsafe abortions in Brazil seems to decrease and the scarcity of data on abortion makes it difficult for the State to act. Goldthwaite and Velásquez (2016) point out that in countries where abortion laws are very restrictive, there are difficulties in anticipating the increase in the number of voluntary abortions (2016).

There is limited knowledge on the incidence of abortion in Brazil. Despite the restrictions, it is not an uncommon event in the reproductive lives of many Brazilians. The results of the 2016 National Abortion Survey (PNA) reveal that one in five women in Brazil up to the age of 40 will have had an abortion by the end of their reproductive life. As in previous years, the social groups with the highest frequency of abortions were rather heterogeneous. Women with low levels of education, black, brown, and indigenous women, and those who lived in the north, northeast, and center-west regions of the country were the groups with a high frequency of abortion, but it was presented in every other social group (Diniz et al., 2016; Pitanguy, 2016). In addition, the survey results also show that, of the 2,002 literate women who were interviewed, between ages 18 and 39, 13 per cent (251) already had at least one abortion. Although, in general, abortions occurred during phases of increased sexual activity. Many also occurred when the women were still quite young: 29 per cent (73) occurred when they were between ages 12 and 19 and 28 per cent (70) occurred between ages 20 and 24 . The percentage decreased to less than 13 per cent (32) when the age was 25 years or older. In 48 per cent (115) of the cases, the women took misoprostol, a drug intended to combat gastric ulcers and listed by the WHO for safe abortion. About 48 per cent of the women also needed to be hospitalized to complete the procedure (Diniz et al., 2016). Data from internet posts on a website aimed at exchanging experiences on abortion reveal how Brazilian women use the procedure to implement their reproductive decisions (Duarte et al., 2020). As mentioned by Arilha (2012), concerning the collectivization of knowledge, women must count on the solidarity of other women as abortion is clandestine. 
The situation becomes even more critical with the realization that the protocol created in March 2016 does not even mention the high incidence of unsafe abortion in the country, the risks of illegal abortion, and the high rates of maternal mortality resulting from unsafe abortions. The protocol excludes the fact that there are cases where abortion is legally supported. Given the clear increase in the demand for abortion due to Zika, the protocol does not guide harm reduction practices nor does it provide measures that can reduce maternal mortality (Baum et al., 2016). There is no guidance on the protocol for women in miscarriage or abortion situations, how to avoid a pregnancy, or how to access more effective and long-term methods, such as the LARC (long-term reversible contraceptive methods) available free of charge in public health units. Intrauterine devices (IUDs), injections, and subcutaneous contraceptive implants, in addition to being reversible and quite effective, do not require any action from the woman for a longer period.

Hence, as argued by Pitanguy (2016), by not guaranteeing full access to reproductive planning and by not reviewing the punitive and restrictive laws regarding access to legal and safe abortion, Brazil does not comply with the recommendations issued on February 9, 2016, by the United Nations High Commissioner for Human Rights for countries facing the Zika virus epidemic (Pitanguy, 2016: 3).

\section{CONSEQUENCES OF THE ZIKA EPIDEMIC FOR THE SEXUAL AND REPRODUCTIVE HEALTH OF WOMEN}

Women who are young, poor, and with low level of education form the group of mothers most affected by the consequences of the Zika virus (Menezes et al, 2019). Most mothers of babies with SCZ live in the northeast region of Brazil, with poor sanitation and housing conditions. These women need to store water, which can increase the risk of mosquito proliferation (Pitanguy, 2016). Historically, this group is also characterized by being the most defenseless in political, economic, social, and health aspects (Diniz et al., 2016; Menezes et al., 2019). Recent changes in policies to grant longterm benefits by the National Social Security Institute (INSS) have left thousands of people, including mothers and children with microcephaly, on the waiting list to receive social assistance benefits (Guimarães, 2020).

Therefore, in the times of Zika, pregnancy became a concern for women, particularly those who live in the areas most affected by the virus (Diniz et al., 2017; Marteleto et al., 2017). The survey conducted by Diniz et al. (2017) collected information from a representative sample of women 
aged 18 to 39, who live in urban areas of the country. This survey reveals that more than half of the interviewees ( 56 per cent) avoided or tried to avoid pregnancy because of Zika. A higher percentage was recorded among the Northerners (66 per cent) compared to the Southerners (46 per cent), reflecting the power of the epidemic in the Northeast of the country. Marteleto et al. (2017) found that the desire to avoid pregnancy was more common among women who had plans to get pregnant before the epidemic. Even though many of these women had unintended pregnancies in the past, the epidemic was not a concern for those who were not considering the possibility of having children and those who revealed that they had already ended their reproductive life (did not want to have more children).

The consequences of the epidemic for reproductive behavior of Brazilian women have been explored in recent literature (Castro et al., 2018; Coelho et al., 2017; Marteleto et al., 2020; Rangel et al., 2019). Several authors analyzed the changes in the number of live births and "in fertility" rates in Brazil during the epidemic (2015-2017). They found declines in the number of live births, suggesting that some women actually changed their reproductive life because of the Zika virus. Despite this, few studies analyze the proximate determinants of fertility and how they varied during the epidemic. For Marteleto et al. (2017), the persistent use of contraceptives may have caused the decline in fertility during Zika. However, in a qualitative study with women of low socioeconomic status, the researchers observed obstacles to the implementation of reproductive choices, such as low contraceptive bargaining power and limited access to paid or free methods.

Bahamondes et al. (2017) point out that contraceptive sales did not increase after the epidemic. According to the researchers, this fact may be another indication that the decline in births occurred due to a more consistent use because abortion might have taken place. Borges et al. (2018) use women aged 18 to 49 in Aracaju (one of the capitals most affected by microcephaly) to investigate the patterns and determinants of discontinued contraceptive use. They observed that a quarter of the interviewees were pregnant when they participated in the study and that almost 60 per cent of these pregnancies were unplanned. The researchers noted that only 1.4 per cent of the women interviewed revealed that they had changed their contraceptive method due to Zika and that among sexually active, non-pregnant, and non-sterile women who did not want to become pregnant (that is, at risk of getting pregnant), 50.9 per cent used moderately effective methods (pills and injectables). 24.9 per cent used ineffective methods (condoms or 
traditional methods), and only two per cent used highly effective methods (IUD). About 22 per cent of them did not use anything.

Another hypothesis for the decrease in the number of births refers to the possibility of higher intrauterine mortality (miscarriage or fetal death). Using research with primates, Dudley et al. (2018) showed that $1 / 4$ of pregnancies ended in miscarriage when primates were infected with the Zika virus in the laboratory, even if they were asymptomatic. Fetal loss and death rates in pregnant primates infected with Zika were approximately four times higher than those generally seen in primate populations that had not been exposed to the virus. The researchers also observed pathological lesions in the fetuses of pregnant primates contaminated by the virus, indicating the harmful effects of the virus. The results obtained point to the need for more studies to develop intervention strategies, which protect pregnant women and their fetuses from the Zika virus. According to the researchers, the timing of infection is an important predictor of fetal loss. Exposure to the virus during the first trimester of pregnancy has a strong correlation with fetal death, which is in line with reports of the disease in humans.

In Brazil, official databases still do not give an accurate estimate of the number of abortions that occur in the country. Despite this, the rate of hospitalization for post-abortion curettage can be used as an indicator for the incidences of abortion. Castro et al. (2018) did not observe variations in hospitalizations for post-abortion procedures (curettage) during the Zika period. On the other hand, Aiken et al. (2016) discovered that, after the Zika epidemic, especially after the relationship between microcephaly and Zika was established by the Pan American Health Organization (PAHO) in November 2015, online requests for abortion medication in international websites have increased significantly. In Brazil, there was a 108 per cent increase in the search for abortion medication. Compared to other Latin American countries that also have legal restrictions on abortion, Brazil showed the highest levels of search.

In this scenario, discussions related to voluntary termination of pregnancy have become more frequent. For many, abortion is still considered a controversial topic, so numerous obstacles are revealed. Some argue that the abortion debate weakens the problems associated with the prevention of Zika and unplanned pregnancy, suggesting that debates should focus on improving sanitation conditions and providing better contraceptive methods. In the absence of scientific work on this topic, the gap on the role of abortion in the epidemic persists. 


\section{DATA AND METhods}

The results presented in this study originate from information collected for the survey Demand and Supply of Medical Care during the Zika Epidemic in Brazil, which was designed to investigate the possible effects of the Zika virus epidemic on the contraceptives and reproductive preferences, as well as its effects on the access and quality of health services in Brazil.

The fieldwork, which took place approximately a year and a half after the beginning of the epidemic in the country, consisted of 16 focus groups with women aged 18 to 49, in the municipalities of Belo Horizonte (MG) and Recife (PE). In each of the municipalities, 08 groups were organized with the participation of 06 to 08 women recruited from different neighborhoods. The criteria for the choice of neighborhoods used in this study include similar rates of mosquito prevalence at the Infestation Index Rapid Survey (LIRAa), proximity to water bodies, contrasting physical structures, and time of day (afternoon and night). A total of 114 women from the focus groups participated in this study.

The focus groups are characterized by the identification of cultural nor$\mathrm{ms}$ and values and the stimulation of an open conversation on more delicate topics (Kitzinger, 2005). Therefore, the use of the technique allowed women, through an interactive process, to discuss abortion-related issues in a Zika virus epidemic context.

The discussions held in the focus groups were guided by a semi-structured script, flexible enough to allow a detailed investigation of questions that were relevant to the discussion. The questions included in the script were designed to gather information about personal and friends' experience with the Zika virus, the sources of information about the virus, use of contraceptives, as well as reproductive history and intentions. Abortion was not an anticipated topic in the script, yet the problem arose organically among the focus groups. The motivations and perceptions of abortion, sources of information, challenges to access a safe abortion in the region and experiences with previous abortions were discussed.

All meetings were recorded with the consent of the participants. The recordings were transcribed for further analysis. The codes were deductively and inductively created in a systematic Grounded Theory procedure (Strauss and Corbin $(1990 ; 1998)$ in Creswell et al. 2007). The research team collectively developed several hypotheses for each of the questions in our interview based on literature. These hypotheses led us to build our initial codebook. Two members of the research team, who have experience 
in Sexual and Reproductive Health and qualitative research, read all the transcripts and added several codes to the codebook (open code) based on the responses of participants who were not provided in the initial hypotheses. Subsequently, the two members took turns coding all the transcripts sequentially. Daily meetings were proposed to discuss possible disagreements regarding a coding application. After coding all the materials, the researchers began to make connections between the codes, allowing the codes to be categorized into main topics (axial coding). The categories were grouped into central categories or thematic networks: access to abortion; abortion in times of Zika; and abortion as a reproductive right.

For this study, three analytical categories are discussed. The first category discusses access to abortion in the perception of the interviewees; the second category presents views on abortion in the face of the Zika epidemic. Finally, the third category addresses women's choices in abortion. This research was approved by the Research Ethics Committee (IRB) of the University of Texas at Austin.

\section{Results}

Access to abortion and questions about the decision to terminate a pregnancy due to the Zika virus were points discussed by the women of the Recife and Belo Horizonte focus groups. Some of the dilemmas and challenges they experienced are presented below.

\section{ACCESS TO ABORTION: FACING DILEMMAS AND FINDING SOLUTIONS}

In Brazil, access to health services remains a dilemma faced by thousands of women who wish to voluntarily terminate their pregnancies. This happens even in cases where such interruption has legal backing (pregnancy represents a risk of life for the woman, when it is the result of rape, and in the case of an anencephalic fetus). Madeiro and Diniz (2016) explain that, although Brazilian law has allowed the termination of pregnancy resulting from rape since 1940, access to health services for the abortion procedure has not been regulated for almost 50 years. It was not until 1989 that a service was provided at the Municipal Hospital Artur Ribeiro de Saboya (SP) for victims of violence. However, to obtain the right to an abortion, women must present a copy of the police report (BO) and the expert report of the Legal Medical Institute (IML). In 1999, with the launch of the technical standard for the Prevention and Treatment of Diseases as a result of sexual violence against women and adolescents, pregnancy resulting from 
violence gained recognition as an important problem. Explicit statements suggested that the lack of information about their rights or constrained access to safe services accounted for women resorting to clandestine abortion services. Abortions performed under such conditions generally have serious health consequences and may even result in the woman's death. In 2005 and 2011, the regulations changed. Women were no longer required to submit BO or IML reports. For the termination of pregnancy due to rape, only the written consent of the woman would be necessary (Cardoso et al., 2020; Ministério da Saúde, 2012).

The process of obtaining adequate assistance faces several obstacles. Voluntary interruption of pregnancy outside the three possible justifications becomes even more complicated, leading to an increasing search for illegal and unsafe alternatives. Cardoso et al. (2020) point out that the illegality of abortion does not prevent its practice, but reveals the existing social inequality in society. This inequality is expressed in the regional differences in the distribution of deaths from abortions observed between 2006 and 2015, despite the tendency of decline. Half of the abortion-specific maternal mortality rate (MMR) occurred among brown-skinned women, especially the group of black women. Inequality was also evident when abortion deaths were analyzed according to the educational level. Cardoso et al. (2020) observed that while death rates decreased for highly educated women, the rates increased for those with low education levels. According to the authors, "... the most vulnerable women are more likely to die after an abortion, even looking only at those who seek public service, who are known to be more subjected to an unsafe abortion" (p. 11- 12).

Many women end up adopting other alternatives. The use of drugs obtained without a medical prescription is confirmed as a common strategy by the participants:

-Moderator: Do you know women who have had an abortion?

-Of course.

-It's easy to get here.

-Depends on the time of pregnancy.

-But not all babies come out, no. (...) I met a 5-month-old girl who had a serious problem. It was her or the baby. At that time, I helped her. She walked, she walked, and she walked. Nobody spoke. I was 7 months pregnant and no one spoke to us. So someone told me to go there [location in Belo Horizonte] and I managed to buy it. (Belo Horizonte, low socioeconomic level).

-Moderator: For a woman who is pregnant here in the community, if she wants to have an abortion, is she able to? 
-Yes, she is. At the pharmacy. I know where it is sold.

-Moderator: But, the pharmacy cannot sell this medication.

-But it's for sale. They sold me 4 pills for 200 reais. I took 2 and applied 2.

-Moderator: And where did you learn to use it?

-Right there at the pharmacy. He said to tell my husband to put two in the applicator and take two more. And it worked. You should see [husband's name] applying the Citotec [laughs] ... (Recife, low socioeconomic level).

As Madeiro and Diniz (2016) have already argued, women still encounter difficulties in accessing abortion services irrespective of the progress made with the 2005 protocol of prevention and treatment of diseases from sexual violence against women and adolescents. The authors emphasized that, although it was no longer necessary, doctors still demanded judicial authorization and a police report for rape before performing the procedure. Women's statements were disbelieved.

Despite being considered a sensitive topic, abortion was mentioned widely and naturally by women in our focus groups. It is worth noting that, every focus group comprised of women with low socioeconomic status, people who knew where to buy the abortion medicine, or people who could indicate a region where they could obtain it. In addition to the stories of friends and acquaintances, people shared many personal abortion experiences. While many participants reported using two or more abortion pills from underground purchases, some also mentioned the intake of teas and natural remedies suggested by friends and family members. These accounts of attempts to terminate the pregnancy, all unsuccessful, expose the accumulation of life-threatening stories.

For many, abortion is a means to avoid conflict and punishment from family. Pregnancy at a very young age and the absence of a stable partner are generally considered an embarrassment. This is aggravated if the woman does not have the financial means to support the child, generating fear, and motivating the adoption of risky behaviors.

-I did it once. But it was because he was 15 years old. If my mother knew, she would kick me out of the house.

-Moderator: And who taught you?

-My colleague. She made a stinky tea early in the morning. But I drank, I threw up and, thank God, my son was born perfectly.

-My sister-in-law, afraid to say she was pregnant, started buying ... everyone taught how to make bottles, teas ... Then, she went and buried a bottle for 7 days with the tea inside. After taking it out, he took it. She drank the entire bottle. She ended up in the hospital, almost died and did not lose the child. 
She took all the medicines that people told her to take. And it failed to abort. (Recife, low socioeconomic status).

Problems with delayed periods and seeking abortion procedures were not only reported by participants with less education and income. In groups of women with higher education and income levels, personal experiences pointed to the use of non-prescription drugs for abortion. However, the speeches of those with more education and higher incomes suggested certain ease in accessing health professionals, abortions services, or specialized interventions in the event of complication during and after the process. Even in the face of complications, there are fewer obstacles to accessing care compared to women of lower socioeconomic status. This situation reinforces the fact that gender relations are still permeated with inequalities and unplanned pregnancies represent a burden for women to make decisions and take action. These were proven by some excerpts from group dialogues.

Moderator: So, if the women in your social class are pregnant, is it possible for them to have an abortion?

-Yes. (All).

-I know a recent case of a person who had an abortion. She got pregnant and just said no. She said: "I don't see myself taking care of a child and I am not going to be able to give that child what they want. One day I want to get pregnant, but not now." So that person went to the doctor, talked to her, and the doctor was super...

Moderator: Was it your doctor?

-Yes. He was super open-minded. He took her in and did the procedure correctly. She had the abortion and had no problems. (Recife, high socioeconomic level).

-Moderator: So, women of high socioeconomic status can seek abortions with their own gynecologist, is that it?

-Not always. I already had an abortion by choice. And it was not easy.

-Moderator: How did you do it? Can I ask?

-Yes. I had to talk to friends to get the medicine to be able to do it. I did it at home, I was with someone, with a friend. But then I had problems. Then I had to go to the hospital, so I had to lie to be able to do the curettage. Anyway, I had to go through this whole situation. (Recife, high socioeconomic level).

The role of friends in abortion is substantial in both groups. Friends and partners monitor the medication intake or accompany the women to carry out the procedure. This is in line with the discourses about women's networks and solidarity in the virtual environment (Duarte et al., 2020). 
The statements presented by the participants contain important elements about the strategies used and how they differed with social class. Although friends and unknown drug providers (smugglers) are part of the reality of the poorest women, women of high socioeconomic status can afford to pay private doctors and count on the discretion of their gynecologists who will not tattle them to the police. In case of emergencies during the abortion procedure, no one will question the private hospital curettage of a highly educated woman, while her low socioeconomic status counterpart will have to rely on the public health system for a hospital procedure to save her life. Afterward, she might face legal problems if proven that her pregnancy was purposely terminated.

At this point, it was not surprising when the participants revealed that abortion attempts by those at a higher socioeconomic level were generally successful compared to those at a lower socioeconomic level with many failed experiences.

The reports suggest that many women employed unsafe and illegal strategies to terminate unplanned pregnancies. As mentioned above, the risks of unsafe abortion are not equally distributed among women and reaffirm the social, economic, political, and cultural inequalities that pervade the country. Abortion is considered a public health concern, owing to its magnitude and prevalence. It is currently the fourth leading cause of maternal mortality in the country and is characterized by being highly selective, exposing the highest risk of death to black and indigenous women with low education, without a partner, and living in the North, Northeast, and Midwest regions of the country (Cardoso et al., 2020; Cofen, 2020; Diniz et al., 2020). The risks imposed on these women reinforce the urgent need for a meticulous review of the laws that establish punitive measures against those who indulge in abortion and the use of contraceptives in Brazil. As Cavenaghi and Alves (2019) argue, family planning programs have never been very successful in the country because access to reproductive health services is difficult for some segments of the population, especially the poorest. Diniz et al. (2020) emphasize that this lapse requires immediate attention because effective contraception can prevent dangerous sexual and reproductive health practices, which will strengthen the Brazilian health system.

\section{The ZiKa VIRUS AND PREgnANCY: ABORTION AS A POSSIBLE PATH}

In Brazil, the emergence of the coronavirus and the Zika virus epidemic has reawakened an old controversy for different sectors of society: sexual 
and reproductive health, including abortion, which provides solutions to the national health emergency in Brazil since 2016 (Baum et al., 2016; Carabali et al., 2018; Diniz et al., 2020; Mohallem and Soares, 2016; Pitanguy, 2016; Ster, 2016; Wenham et al., 2019). However, with the Zika virus disease, the urgency centered on the control of the causative organism, Aedes aegypti, the development of more effective diagnostic methods, and the possibility of developing a vaccine. Women living in the areas most affected by the virus, especially those who were already pregnant, did not benefit from this governmental strategy. This, together with the lack of information about Zika and barriers to accessing health services, aggravates the situation. Many women could not clearly understand how the infection could affect the health and development of the fetus or their babies (Diniz et al., 2020). However, even among them, the possibility of terminating a pregnancy due to Zika virus contamination has not been ruled out. Participants who stood against abortion also argued that the problems generated by Zika justified having an abortion, since the situation was comparable to that of anencephalic fetuses, that is, the chances that the child would have a normal life would be practically zero. Mohallem and Soares (2016) point out that, as in the cases of anencephalic babies, in the cases of microcephaly, the law should not force women to follow a nine-month trajectory of anguish and apprehension.

The media intensely broadcasted the burden of caring for a child with a physical and intellectual disability. In addition to head deformities, babies with seizures, and cognitive deficits, hearing, vision, and swallowing difficulties were also observed. These problems clarified the need for constant specialized monitoring of affected children, with a consequent increase in the cost of childcare. It was not uncommon to find women who were concerned about the emergence of the Zika virus because they knew that a child with microcephaly would never become independent. They were worried about who would care for the child if something happens to the mother.

-Even controlled [mosquito infections], there will be cases. (...) I, as a mother, avoid and do everything to exterminate the breeding sites. But if I got pregnant, I wouldn't think twice about having an abortion.

-My friend got pregnant right at the beginning of Zika. And she said she was going to do the ultrasound and if he got (microcephaly), she would take it out. So I said, oh, don't do that, no. Then she said: would you have it? I said no. Then he said: you don't know what it's like to have a [dependent] child for the 
rest of your life. I would have courage. (Belo Horizonte, high socioeconomic level).

-I have a friend who had an abortion (...). When she found out she was pregnant, there was the Zika issue, and she took it off.

-If you see all these programs, you know what Zika is, you know, I know many women who had dengue, Zika, and then there was a child with microcephaly. So, you are afraid, that's right. (...)

-There are many women who do not accept the child (...) in good health, especially with microcephaly. (Recife, low socioeconomic status).

The concerns raised by the participants in the focus groups did not only include health problems, but also financial resources necessary to cover childcare expenses for a disabled child. For them, the dependence of babies with SCZ is lifelong and can hardly be met with the social assistance benefits offered by government programs, which are difficult to even obtain. Many participants expressed dissatisfaction about the amount paid by these benefits, particularly to children with SCZ. In countries such as Canada, Italy, Germany, France, the United Kingdom, and the United States, legal abortion led to a substantial decline in the costs of medications and hospitalizations of women who had unsafe abortion attempts (Mohallem and Soares, 2016).

Many people wondered: If there are insufficient financial resources available to tackle these obstacles, why have the child? At this point, the possibility of having a legal abortion in the case of microcephaly was highlighted.

-Many people do not accept because they do not have the resources. Because you know that if the child is born with a deficit, the mother will probably not be able to support herself because she will live for the child. And there are no resources here, no. With a family grant, we have to fight all year, sleeping on the streets and everything just to obtain a family grant. So, probably, many people think "there is no financial help, then why am I going to have the child?" Whether we like it or not, we either eat or take care of the child. (...)

(Recife, low socioeconomic status).

-And I think that this abortion with microcephaly should be legal (...). Because if the government cannot avoid this (Zika infections), then the government has to bear the consequences (all agree). Even the consequence that the government is giving is a minimum wage assistance benefit ... A minimum wage for a disabled child? It doesn't matter ... you'll stay the rest of your life ... right? With a minimum wage to support your son, you can't even hire a person to help you ...

-Exactly ... if you can't work? (...) And without your salary. 
- The cost to society is much higher ... it is much higher ...

-Of course. There will be a generation of children there, in the northeast, surely there will be a generation ... that will be more expensive for health services ... And it is something that ... unfortunately it is also the fault of the government, it is our responsibility not to worry mainly about me that I do not use repellent, if a mosquito bites me and I have the issue, everything happens ... we do not take care of ourselves, so an innocent child ends up suffering from the irresponsibility of the government, which should have provided more assistance, funded more research, done more things, then you will have to bear some consequences ... (Belo Horizonte, high socioeconomic level).

As Mohallen and Soares (2016) argue, although Brazilian legislation and its constitutional interpretation have been modernized over the last decades, leading to the overcoming of many paradigms, it is still necessary that "women are protected by law when deciding about their bodies, their convictions and their health" (p. 52). Not knowing if the baby would survive and the certainty that, if he survives, he will have serious health problems is, according to the researchers, a form of physical and psychological torture. The appearance of the Zika virus exposes the need to review the Brazilian legislation on abortion since its criminalization implies harmful consequences for all women in the country.

Despite the legal restrictions and the morality factor involved in the voluntary interruption of a pregnancy, many women choose abortions, due to financial constraints, unemployment, difficulties in the relationship, and even problems relating to family planning (Santiago, 2018). In the focus groups, the woman's decision was discussed in tandem with her partner's choices. The arguments showed that by choosing to continue with the pregnancy, the chances of women encountering a trajectory of loneliness and abandonment are high. Majority of the participants believe that the decision to terminate the pregnancy should be theirs. Therefore, the possibility of abandonment, financial difficulties, and various other challenges posed by raising a child with health problems make abortion a viable option.

I clearly believe (Zika will increase abortions). Like many women, they see this issue of the body as something they choose and it will be their responsibility. "So, are you going to have a child with microcephaly? Marvelous". If you know that you are going to have a child with microcephaly, there will be many women who will make it regardless of the man's choice. You will make this decision because you know what you will face and this confrontation will continue for the rest of your life. The man is here now and not tomorrow, but the son will be his son. And, in this case of microcephaly, it is totally related 
because the woman is left alone and the couples leave, because there is no structure to support this weight. For me, it makes a lot of sense to talk about abortion with women from the more privileged classes. Access to terminate a pregnancy in a way will never be safe, in a way that puts her at less risk, you know? It's a lot ... (Recife, high socioeconomic level).

We say "okay, okay, it's a shared decision. The husband has the right to know that the wife is pregnant" (...) but in the end, whose right is it? It's hers. She chooses whether or not she wants to have an abortion. (...) Whether she wants to or not, she's there, she's pregnant, she's going to carry the baby. And she will often be alone. Because it is very easy for men to disconnect. Children are often raised to think like that, right? (Belo Horizonte, high socioeconomic level).

The influence of traditional gender roles was evident in the statements of some participants. For them, the child is always a female responsibility, since men have the privilege of choice to stay and assume the education of the child together with their partner, or "disconnect" and leave the entire burden of care to the woman. Therefore, the social production of gender is affirmed through recipes that make women responsible for the care of their children (Wenham et al., 2016). That is, through precepts that establish an unequal division of responsibilities and work, women are overwhelmed and much more vulnerable (Biroli, 2018).

It is important to note that many women were also completely against abortion, citing religious and existential justifications, even in the case of fetuses with microcephaly. In these situations, pregnancy and caring for a baby with problems could be seen as a "divine test", as a "plan of God for life". Abortion could generate a sense of "blood from your blood" annihilation. Although they were a minority, some women were against abortion, even in cases where it is allowed by the law, such as rape.

In the focus groups, the polarization of opinions generated debates on the legalization of abortion. Women raised questions regarding female autonomy, which is fundamentally compromised when the right to control their reproductive behavior is limited or non-existent (Biroli, 2018). In addition, these debates have also highlighted the fact that the Brazilian legal apparatus related to abortion directly affects women and their physical integrity, exposing them to risks of death. This debate was prevalent among women with high socioeconomic levels than those with lower socioeconomic levels, regardless of the municipality.

My doctor said that he does not do it. ... I said: "I want to have the power to choose if I want to have the child or not" (...) Then, he went and said: no, no. But my (medical specialty) said that he understands that the person has the ri- 
ght to have a healthy child, so if the person wants, he would refer his patient to another doctor [who could perform it] ... (Belo Horizonte, high socioeconomic level).

I believe that when the woman has the right to decide whether or not she wants to continue with this pregnancy if she has the support of the government and the health system itself, she takes fewer risks. For example, "abortion is legal, I am going to a hospital to get it done and take that child out because I do not want him for x reasons; because everyone has theirs and I will be less at risk". And we see cases of several women who go to clandestine clinics and end up dying. So, I think that from the moment abortion is legalized, even because I am in favor, women are less exposed because they run less risk (...) I am deciding that I have a right over my body to continue that pregnancy or not. (Recife, high socioeconomic level).

Although the issue of abortion is extremely urgent among women of low socioeconomic status, the ideals of the feminist struggle for freedom, equality, independence, and autonomy were not prominent, even though these women present the highest maternal mortality ratios and the highest rates of unintended pregnancies. The poorest are generally concerned about survival (how to get an abortion without spending a lot of money or how to support a child with a disability). Women of better socioeconomic status are more concerned about the quality of their daily lives and deep reflections of inequality that their poor colleagues feel in their skin. Unsafe trajectories triggered by unplanned pregnancies endanger the lives of thousands of women. A review of Brazilian legislation is necessary if the option of interrupting pregnancy must become a viable alternative for women. Not only must it be a viable option, but it must also be safe and backed up by the State.

\section{FinAl CONSIDERATions}

In Brazil and several other Latin American countries, abortion gained more popularity in public and political agendas during the last decades of the 20 th century, with the resumption of democracy. The agreements established during the international conferences, such as the International Conference on Population and Development (1994) and the International Conference on Women (1995), held by the United Nations (UN) played key roles in the reawakening of abortion conversations. In these conferences, abortion was considered a public health problem that deserved the attention of the government and health authorities. However, this did not make the issue less controversial and did not lead to significant changes in the 
laws of several countries, including Brazil, which is still characterized by criminalized abortion, except in some situations (when pregnancy creates a risk to the life of the pregnant woman, when it is the result of rape, and in the case of a fetus with anencephaly).

Although legally criminalized, thousands of women continue to practice abortion as a way to fulfill their reproductive desire. The criminalization of abortion in the country continues to alter the statistics of abortion cases and generates risks to the health and lives of women, particularly those who already face more adverse situations. As argued by Pitanguy (2016) and Baum et al., (2016), Brazilian laws related to the termination of pregnancy are punitive and reinforce the social inequalities that already exist in the country, which prevents women from exercising their power of choice, particularly those with less economic and cultural capital.

The results of this study showed that access to abortion remains a major challenge for women, regardless of their socioeconomic status. Restricted access to health equipment for people excluded from the abortion provision granted by the law makes most women seek and use harmful substances for abortion, such as herbs or bottles, or buy medications without a prescription. The results of these behaviors put women's lives at risk. Many reported that they had severe reactions and needed to seek medical services later to resolve their problems. However, it was not surprising that women of higher socioeconomic status reported receiving professional guidance on where they could receive qualified monitoring for pregnancy termination. This result reveals the inequality of access to health care that persists in the country. This characterizes the reality of women with higher and lower socioeconomic status.

The relevance of friends in this study suggests that restricted access to health services and contraceptive methods is not the only challenge encountered by women who wish to have an abortion prohibited by the law. The emphasis on the role of female friends indicates asymmetries in gender relations that still characterize intimate relationships between men and women. The abortion decision is generally shared with another woman, without the help of the partner. Future studies are required to characterize male participation in decision-making regarding the prevention of pregnancy, the management of pregnancy, or its eventual termination.

Even in the days of Zika, abortion was still a dilemma. The choice to terminate a pregnancy has its dilemmas, even when the fetus is known to be in trouble. The moral, religious, legal, and emotional aspects are interwoven and result in diverse opinions (but not always actions). For most 
of the focus group participants, abortion would not be ruled out if they knew that the baby would have a problem due to the Zika virus. The fear of having a dependent child, the non-acceptance of the baby's problems, the fear of the partner's reaction, and the uncertain future, in addition to the financial demands that lie ahead, were reasons for not having a child or for terminating the pregnancy amid the Zika virus epidemic.

Women who shared their perceptions and experiences (of themselves and their acquaintances) on abortion did so naturally and spontaneously. Although many of them presented contrary opinions on voluntary interruption of pregnancy, they expressed solidarity toward the decision or attitude of those who stood in favor of abortion, especially when situations such as abortion, anencephaly, and microcephaly were mentioned.

The results suggest an urgent need to review the legislation that addresses abortion concerning its criminalization and the provision of safe abortion within the scope of the public health service, which are two different issues. Vector control and the recommendation to postpone pregnancy without improving the offer and access to information and contraceptive methods cannot be seen as the only effective responses against the Zika virus. Furthermore, in a context like this where the possibility of changing the abortion law is not forthcoming, the massive supply of LARC in the public health system could have been a promising strategy to prevent unplanned pregnancies during the months in which the epidemic continued.

\section{Acknowledgements}

This research was funded by the Population Health Initiative, the Population Research Center, and by the grant R24HD042849 awarded by The Eunice Kennedy Shriver National Institute of Child Health and Human Development (NICHD). This research was also supported by grant P2CHD042849, Population Research Center, awarded to the PRC at The University of Texas at Austin by the NICHD and by grant R01HDO91257, Reproductive Responses to the Zika Virus Epidemic in Brazil, awarded to PI L. J. Marteleto. The authors thank Leticia Marteleto for granting full access to the qualitative data.

The authors thank Margareth Arilha for the excellent comments made during XXI Encontro Nacional de Estudos Populacionais (Associação Brasileira de Estudos Populacionais) in 2018, where the first ideas of this paper were presented; and two anonymous re- 


\section{viewers for their careful reading of our manuscript and their insigh- tful suggestions.}

\section{REFERENCES}

Abrasco, C. de E. da A. (ed.), 2016, "Zika vírus: desafios da saúde pública no Brasil", in Rev. Bras. Epidemiol. 19, 225-228. https://doi.org/10.1590/19805497201600020001.

Aiken, A.R.A., Scott, J.G., Gomperts, R., Trussell, J., Worrell, M., Aiken, C.E., 2016, "Requests for Abortion in Latin America Related to Concern about Zika Virus Exposure", in N. Engl. J. Med. 375, 396-398. https://doi.org/10.1056/NEJMc1605389.

Arilha, M.M., 2012, "Misoprostol: percursos, mediações e redes sociais para o acesso ao aborto medicamentoso em contextos de ilegalidade no Estado de São Paulo", in Ciênc. Amp Saúde Coletiva 17, 1785-1794. https://doi.org/10.1590/ S1413-81232012000700017.

Bahamondes, L., Ali, M., Monteiro, I., Fernandes, A., 2017, “Stagnant contraceptive sales after the Zika epidemic in Brazil", in Eur. J. Contracept. Reprod. Health Care 22, 381-383. https://doi.org/10.1080/13625187.2017.1397623.

Baum, P., Fiastro, A., Kunselman, S., Vega, C., Ricardo, C., Galli, B., Nascimento, M., 2016, "Ensuring a rights-based health sector response to women affected by Zika", in Cad. Saúde Pública 32. https://doi.org/10.1590/0102-311X00064416.

Biroli, F., 2018, Gênero e desigualdades: Limites da democracia no Brasil, ed. Boitempo Editorial, São Paulo.

Borges, A.L.V., Moreau, C., Burke, A., Santos, O.A. dos, Chofakian, C.B., 2018; "Women's reproductive health knowledge, attitudes and practices in relation to the Zika virus outbreak in northeast Brazil", in PLOS ONE 13, e0190024. https://doi. org/10.1371/journal.pone.0190024

Brasil, M. da Saúde. S. de A. à Saúde. D. de A., 2016, Protocolo de atenção à saúde e resposta à ocorrência de microcefalia relacionada à infecção pelo vírus zika, Editora MS, Brasilia. Available at https://bvsms.saude.gov.br/bvs/publicacoes/ protocolo_resposta_microcefalia_relacionada_infeccao_virus_zika.pdf

Brasil, Ministério da Saúde, 2015, Protocolo de vigilância e resposta à ocorrência de microcefalia relacionada a infecção pelo vírus Zika. Plano Nacional de Enfrentamento à Microcefalia no Brasil. Brasílea, DF.

Carabali, M., Austin, N., King, N.B., Kaufman, J.S., 2018, “The Zika epidemic and abortion in Latin America: a scoping review", in Glob. Health Res. Policy 3, 15-15. https://doi.org/10.1186/s41256-018-0069-8.

Cardoso, B.B., Vieira, F.M. dos S.B., Saraceni, V., 2020, “Aborto no Brasil: o que dizem os dados oficiais?”, in Cad. Saúde Pública 36, e00188718. https://doi. org/10.1590/01002-311x00188718. 
Castro, M.C., Han, Q.C., Carvalho, L.R., Victora, C.G., França, G.V.A., 2018, "Implications of Zika virus and congenital Zika syndrome for the number of live births in Brazil", in Proc. Natl. Acad. Sci. U. S. A. 115, 6177-6182. https://doi. org/10.1073/pnas.1718476115.

Cavenaghi, S., Alves, J.E.D., 2019, "The everlasting outmoded contraceptive method mix in Brazil and its legacy", in Rev. Bras. Estud. Popul. 36.

Coelho, F.C., Armstrong, M., Saraceni, V., Lemos, C., 2017, “Can Zika Account for the Missing Babies? Front", in Public Health 5, 317. https://doi.org/10.3389/ fpubh.2017.00317

Cofen, 2020, Uma mulher morre a cada 2 dias por aborto inseguro, diz Ministério da Saúde, Document. Cofen - Cons. Fed. Enferm. URL http://www.cofen.gov.br/ uma-mulher-morre-a-cada-2-dias-por-causa-do-aborto-inseguro-diz-ministerioda-saude_64714.html (accessed 7/20/20).

Creswell, J W., Hanson, W.E., Plano, V.L.C., and Morales, A., 2007, "Qualitative Research Designs: Selection and Implementation", in The Counseling Psychologist; $35 ; 236$

Coutinho, A.V., Wetzman, A. Marteleto, L.J., 2021, Zica virus public health crisis and the perpetuation of gender inequality in Brazil, in Health 18, 40. https://doi. org/10.1186/s12978-021-01067-1

Diniz, D., Ali, M., Ambrogi, I., Brito, L., 2020, “Understanding sexual and reproductive health needs of young women living in Zika affected regions: a qualitative study in northeastern Brazil", in Reprod. Health 17, 22. https://doi.org/10.1186/ s12978-020-0869-4.

Diniz, D., Medeiros, M., Madeiro, A., 2016, "Brazilian women avoiding pregnancy during Zika epidemic", in J. Fam. Plann. Reprod. Health Care jfprhc-2016-101678. https://doi.org/10.1136/jfprhc-2016-101678.

Diniz, D., Medeiros, M., Madeiro, A., 2017, “Pesquisa Nacional de Aborto 2016”, in Ciênc. Saúde Coletiva 22, 653-660, https://doi.org/10.1177/0011000006287390.

Duarte, N.I.G., Silva, V.L.M. da, Pinto, L.W., 2020, “A “amiga que já abortou”: um olhar sobre experiências partilhadas em uma comunidade virtual”, in Ciênc. Saúde Coletiva 25, 1689-1698. https://doi.org/10.1590/1413-81232020255.33442019.

Dudley, D.M., Van Rompay, K.K., Coffey, L.L., Ardeshir, A., Keesler, R.I. et al., 2018, "Miscarriage and stilll birth following maternal Zika virus infection in nonhuman primates", in Nat. Med. 24, 1104-1107. https://doi.org/10.1038/s41591018-0088-5.

Garcia, L., 2018. Epidemia do vírus zika e microcefalia no Brasil: emergência, evolução e enfrentamento (Texto para Discussão No. 2368).

Goldthwaite, L.M., Velasquez, G., 2016, "Family planning and the Zika era", in Curr. Opin. Obstet. Gynecol. 28, 499-503. https://doi.org/10.1097/ GCO.0000000000000323. 
Guimarães, L., 2020, "Não tem comida em casa”: o drama das mães de crianças vítimas do zika na fila do INSS. BBC News Bras.

Kitzinger, J., 2005, "Focus Group Research: Using Group Dynamics to Explore Perceptions, Experiences and Understandings", in Holloway, I. (ed.), Qualitative Research in Health Care, Open University Press, Maidenhead, 56-70.

Linde, A.R., Siqueira, C.E., Linde, A.R., Siqueira, C.E., 2018, "Women's lives in times of Zika: mosquito-controlled lives?”, in Cad. Saúde Pública 34. https://doi. org/10.1590/0102-311x00178917.

Madeiro, A.P., Diniz, D., 2016, "Serviços de aborto legal no Brasil - um estudo nacional”, in Ciênc. Saúde Coletiva 21, 563-572. https://doi.org/10.1590/141381232015212.10352015 .

Marteleto, L.J., Guedes, G., Coutinho, R.Z., Weitzman, A., 2020, “Live Births and Fertility Amid the Zika Epidemic in Brazil", in Demography. https://doi. org/10.1007/s13524-020-00871-X.

Marteleto, L.J., Weitzman, A., Coutinho, R.Z., Alves, S.V., 2017, “Women's Reproductive Intentions and Behaviors during the Zika Epidemic in Brazil", in Popul. Dev. Rev. 43, 199-227. https://doi.org/10.1111/padr.12074.

Menezes, N.M., Lima F.M. da S., Souza, F. dos R., Souza, M.P.A., 2019, “Debates acerca dos direitos sexuais e reprodutivos no contexto do zika vírus, que caminho estamos trilhando?", in Rev. Enferm. Atual Derme 87, 9. Available from https:// revistaenfermagematual.com.br/index-php/revista/article/view/484

Ministério da Saúde-Governo Federal Brasil, 2015, Declara Emergência em Saúde Pública de importância Nacional (ESPIN) por alteração do padrão de ocorrência de microcefalias no Brasil. Portaria $\mathrm{N}^{\circ} 1.813$, de 11 de Novembro de 2015. Declaration $\mathrm{N}^{\circ} 1.813$, of November 11th 2015. Declaration of Public Health Emergency of National Concern (PHENC) due to alterations in the pattern of occurrence of microcephaly in Brazil, Brasília, Brazil.

Ministério da Saúde, 2012, Prevenção e tratamento dos agravos resultantes da violência sexual contra mulheres e adolescentes (Norma Técnica).

Miranda-Filho, D. de B., Martelli, C.M.T., Ximenes, R.A. de A., Araújo, T.V.B., Rocha, M.A.W. et al., 2016, "Initial Description of the Presumed Congenital Zika Syndrome", in Am. J. Public Health 106, 598-600. https://doi.org/10.2105/ AJPH.2016.303115.

Mohallem, M., Soares, M.B., 2016, Zika, aborto e autonomia da mulher. Ed. JC. URL https://bibliotecadigital.fgv.br/dspace/handle/10438/19523?show=full (accessed 7/21/20).

Moreira, M.C.N., Mendes, C.H.F., Nascimento, M., Moreira, M.C.N., Mendes, C.H.F., Nascimento, M., 2018, "Zika, protagonismo feminino e cuidado: ensaiando zonas de contato", in Interface - Comun. Saúde Educ. 22, 697-708. https://doi. org/10.1590/1807-57622017.0930.

Pitanguy, J., 2016, “Os direitos reprodutivos das mulheres e a epidemia do Zika vírus”, in Cad. Saúde Pública 32. https://doi.org/10.1590/0102-311X00066016. 
Rangel, M., Nobles, J., Hamoudi, A., 2019, Brazil's Missing Infants: Zika Risk Changes Reproductive Behavior (preprint). SocArXiv. https://doi.org/10.31235/ osf.io/fu8bp.

Roa, M., 2016, "Zika virus outbreak: reproductive health and rights in Latin America", in Lancet Lond. Engl. 387, 843. https://doi.org/10.1016/S01406736(16)00331-7.

Santiago, R.C., 2018, "Saúde da mulher e aborto", in Maia, M.B. (ed.), Direito de Decidir: Múltiplos Olhares Sobre o Aborto. Autêntica Editora Ltda, Belo Horizonte, pp. 21-28.

Schuck-Paim, C., López, D., Simonsen, L., Alonso, W., 2016, "Unintended Pregnancies in Brazil - A Challenge for the Recommendation to Delay Pregnancy Due to Zika", in PLoS Curr. 8. https://doi.org/10.1371/currents.outbreaks.7038a6813f734c1db547240c2a0ba291.

Stern, A.M., 2016, "Zika and reproductive justice", in Cad. Saúde Pública 32. https://doi.org/10.1590/0102-311X00081516.

Strauss, A., and Corbin, J., 1990, Basics of qualitative research: Grounded theory procedures and techniques. Newbury Park, CA: Sage

Wenham, C., Arevalo, A., Coast, E., Corrêa, S., Cuellar, K., Leone, T., Valongueiro, S., 2019, "Zika, abortion and health emergencies: a review of contemporary debates", in Glob. Health 15, 49. https://doi.org/10.1186/s12992-019-0489-3.

\section{Curricular information OF The AUThors}

\section{Raquel Zanatta Coutinho}

Raquel Zanatta Coutinho has a Ph.D. in Sociology (University of North Carolina in Chapel Hill), a Masters Degree in Demography (Cedeplar/ UFMG), a Masters Degree in Sociology (University of North Carolina in Chapel Hill), and a Bachelor degree in Social Communication (UFMG). She is an Adjunct Professor at the Department of Demography at the Federal University of Minas Gerais (UFMG) and a researcher at the Center for Development and Regional Planning (Cedeplar/UFMG).

Email: quelzanatta@gmail.com

\section{Andrea Branco Simão}

Andrea Branco Simão holds a PhD in Demography (Cedeplar/UFMG), a Masters Degree in Sociology (Texas A\&M University) and a Bachelor degree in Social Work (Federal University of Santa Catarina). She is a researcher and visiting Professor at the Regional Development and Planning Center of the Federal University of Minas Gerais (Cedeplar/UFMG). Email: andreasimao@gmail.com

Artículo recibido el 24 de junio de 2020 y aprobado el 06 de septiembre de 2021 